\title{
Aesthetical Value of Architecture of the Great Mosque of Kasunanan Surakarta toward Timelapse Application
}

\author{
Rudy Wicaksono Herlambang ${ }^{1}$ \\ \{rudywicaksono@staff.uns.ac.id ${ }^{1}$ \} \\ ${ }^{1}$ Desain Komunikasi Visual, Universitas Sebelas Maret, Surakarta, Indonesia
}

\begin{abstract}
Promotion media in this modern era have a huge effect on improvement of culturally-significant building tourism potentials particularly in Surakarta City. One of these buildings in Surakarta which still exists to date is the Great Mosque of Surakarta. The Great Mosque of Surakarta had long been established as one of Surakarta's historical buildings because the city was one of centers of government in Java at the times of Mataram Islamic Kingdom. This study aims at exploring the aesthetics of beauty of the Great Mosque of Surakarta so that it has a tourist appeal. This study used the qualitative research with multidisciplinary approach, combining historical research with field research (ex post facto). The result shows that the Great Mosque is rich of philosophical values contained in its architectural arts. Positive messages and images intrinsically shown in the Great Mosque are then put together in a form of aesthetics produced through time-lapse technique in a promotional video. This research has an implication that a positive image exists in the preservation of culturally-significant building resulting from the production of the branding video of the Great Mosque of Surakarta.
\end{abstract}

Keywords: great mosque of Kasunanan Surakarta, architecture, time-lapse

\section{INTRODUCTION}

Surakarta has a diversity of cultural heritages and becomes one of the icons of cultural cities in Central Java ${ }^{[1]}$. As an icon of Javanese culture, Surakarta has tourism potentials due to its cultural richness, encouraging the local government to manage its tourism in order to jumpstart the economy ${ }^{[2]}{ }^{[3]}$. Presently, it is really important to develop city image, and therefore many cities in the world use strategies to introduce their tourism potentials by creating city brandings ${ }^{[4]}$. After the global economic crisis, many countries have started to designate tourism as a base for foreign exchange acquisition ${ }^{[5]}$. Branding can be utilized to give a unique identity to a city in order to distinguish itself from others ${ }^{[6]}$, to create perceptions and images to the consumers, and to support a country to compete in global market and attract tourists from abroad and investors ${ }^{[7]}$. Community role is also important in supporting a city's branding effort ${ }^{[8]}$. The main goal of city branding and the result expected by its government are to raise tourism rate and investments ${ }^{[9]}$. 
Branding strategy can be conducted by making promotional videos about things attractive and iconic to the city. Brand videos are made to introduce Surakarta to the public. They can be utilized to show the city's tourist destinations. Attractive and unique promotional videos are potential to draw visitors ${ }^{[10]}$. Videos can also send promotional messages in an entertaining media and are potential to initiate engagement with the audience in choosing tourist destinations. Brand videos can be a two-way communication service between its producers and consumers ${ }^{[11]}$. The audiovisual media can be a promotional video which represents Surakarta's tourist destinations and is expected to introduce the city ${ }^{[12]}$. Nowadays, promotional efforts can be done by uploading photos or videos related to a tourism icon in a region to attract tourists, without much cost, only using internet connections ${ }^{[13]}$.

The icons of Surakarta frequently displayed in the video are historical buildings of Surakarta's cultural heritage. Indonesian history, rich in traditional values and greatly upholding ancestral culture can attract tourists to visit historical places in order to learn and understand Indonesian history and culture in the past ${ }^{[14]}$. These historical buildings are also known as cagar budaya (culturally-significant buildings). One of these buildings in Surakarta which still exists to date is the Great Mosque of Surakarta. The Great Mosque of Surakarta had long been established as one of Surakarta's historical buildings because the city was one of centers of government in Java at the times of Mataram Islamic Kingdom ${ }^{[15]}$. Its exotics can be utilized as one of Surakarta's cultural icons through appropriate application of branding strategy.

This research discusses about the aesthetical value of the Great Mosque of Surakarta as one of the city's culturally-significant buildings, through the application of time-lapse video technique as a strategy of branding Surakarta's culturally-significant building. There has been many studies discussing culturally-significant buildings of Surakarta. In the previous research, Xiong et.al. (2018) discussed about photography learning to predict cloud movements by presenting the two-step approach of generative adversarial network in order to produce a realistic time-lapse video with high resolution [16]. However, this research is focusing its research scope in the Mosque's architecture style and its philosophical value, through the making of brand video in order to successfully transfer philosophical messages to the audience.

\section{RESULT \& DISCUSSION}

In this section, analysis of aesthetical value in culturally-significant building of the Great Mosque of Surakarta through making of brand video with time-lapse video-taking technique is discussed. The analysis was conducted to observe esthetical meanings in each artistic building in the Great Mosque of Surakarta complex which were combined with the making of brand video taken by using time-lapse technique to build a positive image to architecture art of the Mosque distinctiveness and esthetical value of time-lapse technique in capturing the Great Mosque architecture. The Great Mosque (Masjid Agung) is located west of Alun-alun Utara (North Square). It is one of components of Catur Tunggal (literally "four unities") in Mataram traditional city layout and functions as the place of worship and ceremony processions of the Keraton (palace). An example of this can be seen during Garebeg ceremony held in Maulud, Syawal, and Besar month of Javanese calendar, in which during Gunungan procession, palace guards carrying the gunungan on their shoulders go outside the palace to the Great Mosque so that the gunungan is prayed for before it is given to the people. TheGreat Mosque of Keraton Surakarta Hadiningrat was built by Sunan Paku Buwana IV, reigning in 1788-1820[17]. The Great Mosque complex consists of a front court, surrounding walls, and several building 
consisting of the main building (front porch and main praying room), and several supporting buildings. Ritual functions of the palace mosque are present during Dhuhur, Ashar, Maghrib and Isya' times of prayer. The five praying times of rukun Islam are held routinely and continuously here. Friday, Eid al Fitr', and Eid al Adha prayer gatherings are also conducted by holding steadfastly to Quran guidance. Worship in the Great Mosque is also supported by complete and aesthetical facilities. This factor also becomes an attraction point to the congregation to worship here. Its minaret functions as the adzan calling place, and a pious ambience of entering praying time is heard extensively around the mosque and Keraton Surakarta [18].

The Great Mosque of Surakarta or Solo Great Mosque, which in the past was the Great Mosque of Surakarta Sunanate, is supplied by the kingdom for its needs and the building complex itself is used to hold the kingdom's religious ceremonies. All employees of the Mosque are the king's servants (abdi dalem) and are given noble titles, such as Kanjeng Raden Tumenggung Penghulu Tafsiranom (penghulu, marriage official) and Lurah Muadzin. Mosque is a cultural artifact or product related to system of ideas and activities of the community. Developments related to the Great Mosque are intertwined with religious education and the belief system of its supporting society, so that each corner of architecture in the Mosque is rich in meaning. The work of architecture and interior as a form of culture not only answers various problems in function; its physical manifestation also accommodates human activity.

The gates are the entrance to the Mosque complex. It consists of brick walls with three door holes. The entrance is shaped like pointed/broken arches, such as seen in arches of mosque architecture in Cairo, Egypt, or in pointed arches of Gothic architecture in Europe. In the upper middle region, or on top, there are several boulders shaped like Javanese king crown attached. The main building consists of two rooms, the serambi/pendopo (receiving hall), an open, wall-less room, and walled main prayer room inside, with doors and windows. The receiving hall is square-shaped and has three-tiered joglo $\neg$-style roofing. Traditional in its construction, it is constructed from wood and the roof covering uses wood shingles. The main prayer room building is rectangular, and has three-tiered tajug-shaped roofing. Traditional in its construction, it is also constructed from wood and the roof covering uses wood shingles. Philosophical meanings of the architecture pattern are also depicted in each corner of the Great Mosque building.

Table 1. Philosophical meanings from apart of Great Mosque of Surakarta.

$\begin{array}{ll}\text { Object } & \text { Philosophical Meaning } \\ \text { Paduraksa Gate } & \begin{array}{l}\text { Gate and entrance for three } \\ \text { directions of the Mosque, } \\ \text { symbolizing majesty and } \\ \text { holiness of the main building } \\ \text { inside. }\end{array} \\ \text { Main entrance } & \begin{array}{l}\text { Brown in color, representing } \\ \text { modesty }\end{array} \\ & \end{array}$


Three tiers of the Three tiers of religious Mosque in the achievement, related to concepts floor, wall, and found in Hinduism: bhurloka, roofing human world; bhuwarloka, the world of death; and swarloka, the world of gods.

Brown rectangular Symbolizing human modesty in shapes in the main worldly life and contains room (columns, sacredness at an upper level roofing, windows, than in other rooms. doors, mihrab, mimbar)

Mihrab

Mimbar

Column

constructions

(four saka gurus)

Roofing constructions
Giving perception that mihrab is a place considered as sacred, as the center of theological orientation between human and their God (Allah SWT)

Representation of the place to deliver Friday sermons, which is a condition for the validity of Friday Prayers and feast prayers. Sermons delivered are the straight teaching of Islam

Worldly life has four elements of strength, namely fire, water, air, earth, which are derived from the Almighty Creator

Tajuk-style (pyramidal), with a three-tiered roof and culminating in mustaka (crown), symbol of the return of human nature to the presence of God
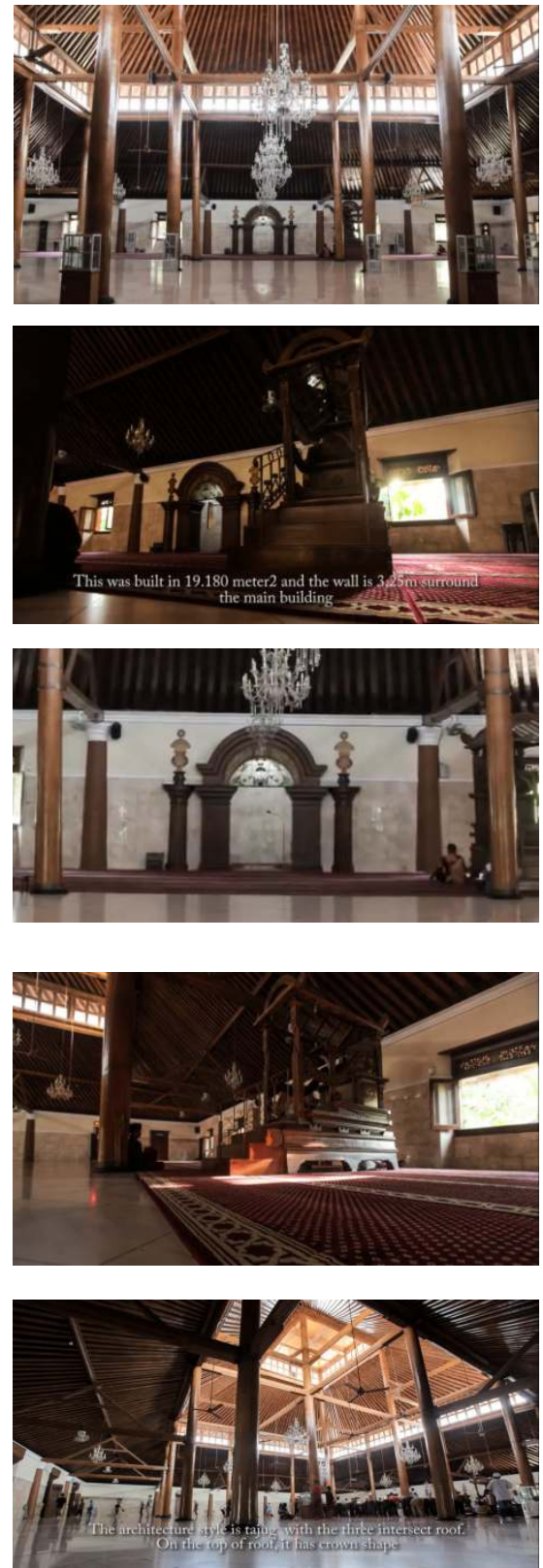
The the grandeur of the Great Mosque of Surakarta which is a part of the long history of the Palace of Kasunanan Surakarta evidently contain many philosophical values in every corner of its architecture. Its aesthetic values are proofs that there were acculturations between the Hindu culture and the Islamic culture during the reign of Mataram Islamic Kingdom in Java Island as proven by the mosque gate which is architecturally similar to Hindu buildings. Philosophically, the mosque gate is a symbol of entrance door to sacred buildings in Hinduism. In the main building of the inside part of the mosque, its aesthetics and grandeur are shown by the architecture of the floors, walls, and roofs of the mosque. This philosophical context symbolizes the materialization of the good relationship between men and the good relationship between men and their God. The dominating brown color contour is the materialization of the modesty of earthly or worldly life. The pillars of the mosque, consisting of four and locally called as papat saka guru (the four main pillars of the mosque building), are symbols of the four main elements of life, namely: fire, water, air, and soil. The pyramidal-shaped canopy with mustaka (head) peak is a symbol of inevitability that human beings as creatures which are created by God will eventually return to their creator. There are so many philosophical values found in the study of the Great Mosque of Surakarta, and they shall be known to the public. The role of video branding in packing the contents, namely: aesthetic architectural style of the mosque and its panorama \& philosophical values is very much required as a message-delivery media.

Photographic time-lapse is a cinematography technique, in which the frequency of time for principal photography is longer than the video result. The objects and periods of time taken days or months can be seen only in minutes or seconds [19]. Time-lapse technique is a video animation, consisting of several photos placed in order until they are seen like moving as in video recording. Time-lapse is a combination between photography and video editing techniques. In using this technique, beautiful photos can be enjoyed in a video, by taking several successive photos in several periods, then placing the photos in order to become a video [20]. In the beginning, the aim of time-lapse photography was to satisfy research needs, in which very slow movements were recorded and shown for the movements to be observed (contrary to slow-motion video). For extremely slow movements, time-lapse video can be recorded periodically in minutes (not seconds), such as when learning plant or flower growth, the researcher photographed the object every 15 minutes for days [21].

A video using time-lapse video-taking technique can offer esthetical values, pushing viewers into an atmosphere or an object. Time-lapse technique shows the slow transformation of periods as an actual representation of clanging noises of Surakarta's spirit of culture. The esthetic emerges by presenting the ambience of naturally-changing conditions of object setting without any engineered changes. It shows more the real condition happening in a culturallysignificant object in a relatively long period of time which enables changes to occur. The technique encourages viewers' perspective about natural or social activities happening in an object, and the object's beauty can be portrayed after combined in an audiovisual media project.

In perspective, the making of brand video of the Great Mosque of Surakarta by using timelapse technique successfully shows a detailed image in depicting the Mosque. Camera movement in this video happen a few times, but in a slow and structured way. Camera focus in this video, which is the culturally-significant building and surrounding community activities are depicted clearly. In using this technique, one has certain strength of being able to shoot in places lacking of light. Lighting in this video employs natural light appropriate to time of shooting. Good lighting enables people to see objects they work in a clear and fast way. 


\section{CONCLUSION}

Developments related to the Great Mosque are intertwined with religious education and the belief system of its supporting society, so that each corner of its architecture is rich in meaning. There have been many researches which discuss aesthetics, conceptions, and architectural styles of the Great Mosque of Surakarta. However, this study has found philosophical values which are much contained in every corner of the architecture of the Great Mosque of Surakarta such as those contained in the brown color of the front gate, roof, mihrab, to the pulpit represent modesty. The foundation steps are a form of Hindu acculturation which symbolizes human world, the world of death, and the world of gods. The construction of supporting columns known as papat saka guru symbolizes four elements of life: water, earth, fire, and air, coming from the Almighty Creator. The roofing constructions represent Iman, Islam, and Ihsan, topped with Mustaka representing the nature of humans coming back to their Creator, the One Almighty God. These messages and philosophies, contained in each artistic style of the Mosque, can be delivered through video branding. Time-lapse technique encourages the viewers' perspective of natural and social activities generated by an object, and its beauty can be portrayed after it is coupled with an audio visual media project. In relation to the use of time-lapse technique in the making of video branding of the Great Mosque of Surakarta, the taking of the resulting pictures is very detailed to describe an object.

\section{REFERENCES}

[1]. Kusumastuti, 2016, Proses dan Bentuk "Mewujudnya" Kota Solo Berdasarkan Teori City Shaped Spiro Kostof, Region, Vol. 1, No. 1, pp. 1-51

[2]. Zaida, Suci Nur Aini, Arifin, Nurhayati H. S., 2010, Surakarta: Perkembangan Kota Sebagai Akibat Pengaruh Perubahan Sosial Pada Bekas Ibukota Kerajaan di Jawa, Jurnal Lanskap Indonesia, Vol 2, No 2

[3]. Laksana, Praditiya Budi, Riyanto, Said, Abdullah, 2015, Strategi Pemasaran Pariwisata Kota Surakarta Melalui City Branding(Studi pada Dinas Pariwisata \& Kebudayaan Kota Surakarta), Jurnal Administrasi Publik (JAP), Vol. 3, No. 1, pp. 73-79

[4]. Jannah, Bidriatul, Arifin, Zainul, Kusumawati, 2014, Pengaruh City Branding dan City Image Terhadap Keputusan Berkunjung Wisatawan Ke Banyuwangi, Jurnal Administrasi Bisnis (JAB), Vol. 17 No. 1

[5]. Chaerani, Ratu Yulya. 2011. Pengaruh City Branding Terhadap City Image (Studi Pencitraan Kota Solo: 'The Spirit of Java'). Jurnal Riset Komunikasi. Vol 2, No 4

[6]. Purwianti, Lily, Lukito, Yulianty Ratna Dwi, 2014, Analisis Pengaruh City Branding Kota Batam Terhadap Brand Attitude (Studi kasus pada stakeholder di Kota Batam), Jurnal Manajemen, Vol.14, No.1

[7]. Utami, Sri, Gaffar, Vanessa,2014, Pengaruh Strategi Nation Branding "Wonderful Indonesia" Terhadap Proses Keputusan Berkunjung Wisatawan Australia Ke Indonesia, Tourism and Hospitality Essentials (THE) Journal, Vol.IV, No.1, pp. 693-704

[8]. Kusuma, Arifin Fafan, Darwanto, 2015, Nilai-Nilai Modal Sosial yang Terkandung Dalam Perkembangan Pariwisata (StudiKota Solo), Jurnal Bisnis dan Ekonomi (JBE), Vol 22, No. 1, pp. $65-84$

[9]. Kavaratzis, M. 2004. From City Marketing to City Branding: Towards a Theoretical Framework For Developing City Brands. Place Branding, Vol. 1, No. 1, pp: 58-73 
[10]. Fong, Yang Lai, Dyuty Firoz \& Wan Idros Wan Sulaiman, 2017, The Impact of Tourism Advertisement Promotional Videos on Young Adults, Journal of Social Sciences and Humanities, Vol. 12, No. 3, pp. 1-16

[11]. Raney, A. A., Arpan, L. M., Pashupati, K., \& Brill, D. A., 2003,At the movies, on the web: An investigation of the effects of entertaining and interactive web content on site and brand evaluations, Journal of Interactive Marketing, Vol. 17, No. 4, pp. 38-53

[12]. Swari, Laila R., Lakoro, Rahmatsyam, 2016, Perancangan Video Promosi "Jelajah Pantai Tulungagung" untuk Menunjang Potensi Wisata Pantai di Kabupaten Tulungagung, Jurnal Sains Dan Seni ITS, Vol. 5, No.2

[13]. Atiko, G., 2016. Analisis Strategi Promosi Pariwisata Melalui Media Sosial Oleh Kementrian Pariwisata RI. Skripsi. Program Studi Ilmu Komunikasi Universitas Telkom

[14]. Permana, Aan Ari, Fianto, AchmadYanu Alif, Yosep, Sigit Prayitno, 2015, Penciptaan Destination Branding Keraton Kasunanan Solo Sebagai Upaya Meningkatkan Minat Kunjungan Wisatawan Domestik, Jurnal Desain Komunikasi Visual, Vol.4, No.1

[15]. Suratman, D., 2000, Kehidupan Dunia Keraton Surakarta 1839 - 1930, Yogyakarta: Yayasan Untuk Indonesia

[16]. Xiong, W., Luo, W., Ma, L., Liu, W., \& Luo, J., 2018. Learning to Generate Time-Lapse Videos Using Multi-Stage Dynamic Generative Adversarial Networks. The IEEE Conference on Computer Vision and Pattern Recognition (CVPR), pp. 2364-2373

[17]. Ave, J., 2004. Karaton Surakarta. Jakarta: Jaya Agung Offset.

[18]. Yunianti, E., 2015. Estetika Unsur-Unsur Arsitektur Bangunan Masjid Agung Surakarta. CATHARSIS. 4(1), 2015. pp. 15-23

[19]. Chylinski R, Timelapse Photography, 2012 hal 12-14

[20]. Herdian, D. I., Ramadhian, A. T dan Jani, K. 2015.Produksi Video Dokumenter Museum Radyapustaka di Surakarta dengan Mengaplikasikan Teknik Timelapse.Electrionic Publication Informatic Technique Faculty of Technique Alectrical and Informatic. pp. 116 